\title{
Behind the Youthful Facade: The Church of Sweden Abroad and Its Older Visitors and Volunteers
}

Annika Taghizadeh Larsson and Eva Jeppsson Grassman

\author{
Linköping University Post Print
}

Tweet

N.B.: When citing this work, cite the original article.

Original Publication:

Annika Taghizadeh Larsson and Eva Jeppsson Grassman, Behind the Youthful Facade: The Church of Sweden Abroad and Its Older Visitors and Volunteers, 2014, Journal of Religion, Spirituality \& Aging, (26), 4, 340-356.

http://dx.doi.org/10.1080/15528030.2014.880774

Copyright: (C) Taylor \& Francis Group, LLC http://www.tandfonline.com/

Postprint available at: Linköping University Electronic Press

http://urn.kb.se/resolve?urn=urn:nbn:se:liu:diva-111215 


\title{
Behind the youthful façade: the Church of Sweden Abroad and its older visitors and volunteers
}

\begin{abstract}
This article addresses the role of the Church of Sweden Abroad, with its 45 parishes in foreign countries, for older Swedes who live or stay abroad, permanently or for long or short periods. The article is based on a research project comprising three studies: a qualitative study, an analysis of websites and information material, and an internet-based survey. The results highlight the important role played by the parishes for older visitors, in terms of providing community, support and religious services. However, people above the age of 65 were virtually invisible on the church websites and in other information material. This paradox will be discussed and the concept of ageism is used in the analysis.
\end{abstract}

Keywords: migration, older people, ageism, the Church of Sweden, ethnic congregations

\section{Introduction}

Since the 1990s, a growing body of literature has revealed that migrants may contact and become involved with immigrant religious congregations for a variety of reasons (Cadge \& Howard Ecklund, 2006; Furseth, 2008) and that the consequences of such involvement are multifaceted. For example, ethnic congregations have been shown to play an important role for migrants in delivering social services and in facilitating the process of adaptation in the new country (Ebaugh \& Chafetz, 2000). Having the opportunity to practice their faith with like-minded people in a congregation creates togetherness and security (Ebaugh \& Chafetz, 
2000; Peschke, 2009; Sjödin, 2011). Ethnic congregations have also been shown to function as effective institutions for cultural preservation, helping delaying loss of the mother tongue (e.g. Hagan \& Ebaugh, 2003; Beattie \& Ley, 2003; Aagedal, 2007). Engagement in ethnic congregations has, on the other hand, also been described as sometimes working as a "buffer" against integration in the new host country (Min, 1992; Ebaugh \& Chafetz, 2000).

Corresponding to an old and established sociological explanation of why people tend to turn to religion (Zuckerman, 2009), the needs of migrants to adhere to an ethnic congregation have generally been explained as an expression of the difficulties connected with migration and to experiences of racism, exclusion and discrimination in the new country (e.g. Hagan \& Ebaugh, 2003). However, few studies (see e.g. Gehui \& Heying, 2009) have focused on older migrants and their contacts and involvement with ethnic religious communities in the new host country. This despite the fact that church participation appears to increase with age and that older persons in general demonstrate significantly higher levels of religious involvement compared to young adults (McFadden, 1995). Even fewer studies, if any, have been oriented towards the question of how older people are portrayed in presentations and marketing of churches on websites, a forum that has come to be of increasing importance for religious organizations as a way to communicate and disseminate information (Campbell, 2011). Based on a research project consisting of three studies exploring the Church of Sweden Abroad, this article addresses these gaps in the literature on religion and migration.

Focusing on the older (age 65 and over), Swedish migrants with whom the Church of Sweden's parishes abroad, in various ways, come into contact, the overarching questions addressed are: What role do the parishes abroad play in the lives of older Swedish migrants? What proportion of the church visitors are over 65 years, and who are these older Swedes? How do the older church visitors contribute to the activities in the parishes? How are older 
Swedes presented on the parishes' websites and in other information material about the

Church of Sweden Abroad? This last question is particularly important since all parishes of the Church of Sweden Abroad have web pages in which the parishes and their activities are presented in words and pictures. Additionally, the Church of Sweden Abroad has its own space on the official website of the Church of Sweden. Thus, in the globalized world of today, a Swedish migrant's first contact with a local Church of Sweden Parish Abroad might well be through its website.

While the question concerning websites was studied through an analysis of written texts and pictures, the other research questions were primarily studied from the perspective of the pastors and of the deacons (who are in charge of the parishes` social work). However, through site visits, observations and qualitative interviews, the perspective was broadened, and through interviews with a number of older active Swedes the important perspective of the older church visitors was included to some extent.

\section{The Church of Sweden Abroad}

The Church of Sweden has a long tradition of creating parishes abroad, mainly in the larger European cities and in connection with harbours, where it set up Seamen's Churches. In some larger cities, there are Swedish parishes with a history dating back several centuries. An illustrative example is the Swedish parish in Paris, with roots going back to the early 17 th century. Since the 1960s, however, the Church has followed the migration patterns of Swedish tourists and seasonal migrants. Parishes have been established in Southern Europe, primarily in Spain and, recently, in some Asian countries. To date, the Church of Sweden Abroad comprises around 40 parishes located in 45 places, in 25 countries (Svenska kyrkan, 2011a). The formal assignment of all parishes of the Church of Sweden is to "offer religious 
worship, education, missionary work and to provide diaconal social work" (Svenska kyrkan, 2011b). ${ }^{1}$ This also goes for the Church of Sweden Abroad. In addition to the general assignment, the Church stresses the social mission of the parishes abroad. Their role is to offer Swedes who are staying abroad for long or short periods, religious worship and rites in Swedish, pastoral care, support in crises and disasters, and a Swedish social meeting place (Svenska kyrkans utredningar 2009:1).

\section{Perspectives and contributions}

With a focus on the Church of Sweden Abroad and on older, retired Swedish migrants, this article aims to contribute to the research area within the study of religion that specifically studies immigrant religious communities, or ethnic congregations, and their visitors; that is, congregations which, like the parishes of the Church of Sweden Abroad, are primarily intended for, or attract, a specific (ethnic) group of migrants.

In the last few decades, scholars in this field of research have highlighted the role of immigrant religious communities in catering to a variety of needs among migrants in vulnerable situations. However, although there is substantive research on immigrant religious communities and their roles and functions for migrants, few works have focused on older migrants. Additionally, few studies concern voluntary migrants from northern European countries. This also applies to research on the contemporary role of the Nordic majority churches abroad (see however Kverndal, 1986; Aagedal, 2007). Concerning the role of the

\footnotetext{
${ }^{1}$ The Church of Sweden was, until the year 2000, a State Church. Until 1951, membership in the Church of Sweden was obligatory. In 1996, automatic adherence - that babies were "born into" the Church if at least one parent was a member - was abolished. In recent decades, membership rates have gradually decreased. In 1973, as much as 95 percent of the population were still members of the Church of Sweden. In 2012, the equivalent percentage was around 67 percent. However, "active membership" is rare and very few people are regular churchgoers. According to some studies, such as the World Values Survey, Sweden can be regarded as one of the most secularized countries in the world (Inglehart et. al., 2004).
} 
Church of Sweden Abroad for Swedish migrants there are a few historically-oriented studies (published in Swedish), some of which are oriented towards specific parishes abroad (e.g. Bergmark, 1974; Murray, 1980; Bäckström, 1995;). Regarding the contemporary role of the Church of Sweden Abroad and its parishes all over the world, the current project appears to be the first one to address this subject, apart from some evaluations conducted in recent years by the Church of Sweden itself (e.g. Svenska kyrkans utvärderingar 2001:1, 2009:1). This article thus touches on several rather unexplored areas.

\section{Methods and materials}

The analysis presented in this article is based on results from a project that focused on the role of the Church of Sweden Abroad. This project aimed to explore the parishes of the Church of Sweden established in foreign countries, considering their roles and activities, with particular focus on migration, ageing and the last phases of life. The project consisted of three studies.

Study 1 was a qualitative study, based on site visits and data collection in 12 parishes in various countries. Strategically, we chose to include three larger cities (Paris, Berlin and New York) and two cities with a port (Piraeus and San Francisco), all of which, except for Piraeus, were characterized by "old Swedish immigration". We also included six southern European tourist resorts in three different countries (Gran Canaria, Tenerife, Fuengirola and Torrevieja in Spain, Nice in France and Ayia Napa in Cyprus) where Swedes live permanently, stay on a seasonal basis, or have visited as tourists for many years. Furthermore, we included a parish (in Phuket, Thailand) that has recently been established. Data were collected through semistructured interviews with 11 pastors and five deacons on mission from Sweden and who worked in the parishes, and also with 18 older Swedes, most of whom were active in the parish. The interviews, which were based on open-ended questions and lasted $1-1.5$ hours, 
were recorded and then transcribed verbatim. The interview guide used in the interviews with pastors and deacons included five sections: 1) characteristics of the parish (location, size, age, number of Swedes in the area, etc., 2) characteristics of the visitors, 3) the role and importance of the parish, 4) specific activities and 5) types of support in the end-of-life phase. We also carried out observations in and around the Church premises for one or two days in each parish.

Study 2 consisted of a scanning and a directed content analysis of the web pages of all the parishes in the different countries and of the space occupied by Church of Sweden Abroad on the official, central website of the Church of Sweden. We also analysed different forms of information material about the Church of Sweden Abroad (brochures, etc.). The focus was on how - and if - older people and later life-related phenomena (retirement, age-related diseases etc.) were addressed in written texts and in pictures. ${ }^{2}$

Study 3 was an Internet-based survey with multiple choice, as well as open-ended questions. The survey was distributed to all Church of Sweden parishes abroad. Responses were obtained from 39 of the 40 parishes that were included. (Five parishes could not be included for various reasons such as that the parish was temporarily closed or only active in the summer). Thirty-two pastors and seven deacons responded to the survey. The questionnaire included 37 questions that paralleled the questions in the interview guide of Study 1.

\section{The parishes' older visitors and volunteers}

\footnotetext{
${ }^{2}$ The Church of Sweden has an overall editorial policy that is mirrored in its central website. The responsible person here is the general editor. However, the parishes have their own websites which are usually created by the local employees as editors.
} 
Who are the typical visitors in the parishes of the Church of Sweden abroad? The survey responses indicated that there were variations between the parishes in this respect. However, according to these responses, in more than half of the parishes (60 per cent), a majority of the regular visitors were aged 65 or older. In total, approximately 40 per cent of the church volunteers were 65 or older. Particularly in the parishes located in the southern European countries, there seemed to be many retirees among the churchgoers, many of whom spent several months in the local community each year. A survey-respondent from one such parish, for example, stated that 90 per cent of the visitors and volunteers in the winter season were 65+. Corresponding patterns were found in other churches in Southern Europe. Also in some of the larger cities, persons aged 65 and older constituted the majority of the visitors and volunteers in the parishes, according to the survey responses.

It is clear, both from the responses to the open-ended survey questions and from the observations and qualitative interviews with pastors, deacons and with older Swedes, that the older Swedes who visit the parishes do not form a uniform category. There proved to be significant variations, not least in terms of religiosity and previous relation to the Church of Sweden. During our site visits to parishes in different parts of the world, we met a wide range of older people. While some said that they had been believers throughout their lives and had been frequent churchgoers while still in Sweden, most of the older Swedes said that it was here, abroad, that they had started to go to church regularly. We even met people who, although they were no longer members of the Church of Sweden "at home", said that they visited the parish abroad in question "basically every day".

The heterogeneity among the older visitors, revealed in the survey responses as well as during our site visits, concerned more than religiosity and previous relations to the Church of 
Sweden. It also had to with whether they were temporary tourists, older Swedes who had immigrated to, or begun to spend much of the year, in the country or place in question after their retirement, or people who had left Sweden at a younger age and lived in the country since then and for many years. While the migrants who had left Sweden at a younger age, perhaps unsurprisingly, seemed to be well integrated in the new country, the opposite was true for many of the retirement migrants. These migrants, who made up a large proportion of the church visitors in many of the parishes located in the southern European countries, appeared to be a rather diverse group in terms of social class and education. Also in terms of health, these older visitors appeared to be a rather heterogeneous group. In some parishes, the majority of retirement migrants seemed rather well off, both in terms of economics and health. On the other hand, in some other places, a high proportion of the visitors were much older people, neither wealthy nor healthy. They were Swedes (and Norwegians) who, winter after winter, stayed in one of the empty hotels or in holiday flats, for a relatively low offseason price. Many of them were very old (aged 85-90) and in several cases were frail and in need of care. A similar pattern was found for older tourists, many of whom were frail and much in need of the attention of the parish. A central theme for people belonging to these groups seemed to be the problem of bringing an end to their seasonal migration, or, for those who were regular tourists, to accept that they no longer had the strength to travel. Some of the interviewed older people described their travelling as such an important part of their life that only death or a very severe illness could put an end to it.

\section{What role do the parishes play for older Swedes?}

One question, in the qualitative interviews with pastors and deacons (Study 1), and in the survey questions (Study 3), had to do with whether, in the respondent's opinion, the parish had any particular importance for older Swedes in the area. Many of the pastors and deacons 
whom we interviewed during our site visits stressed that the parish's aim was to create a feeling of security, a sense of community and a sense of belonging, not least for older Swedes. According to some of these respondents, the parish functioned both as a meeting point and as a "guarantee" for them: "Many older Swedes would not be able to be here if the Church was not here. They know that they can turn to us if something happens" (pastor in the parish in Cyprus). In the survey, this response was confirmed: 90 percent of the respondents stressed the importance of the parish for older visitors.

The parish was also considered important as a provider of care and support for those older Swedes who lived alone and for those who were ill and frail. Just over 37 per cent of the pastors and deacons who participated in the survey reported that their parish often had contact with older Swedes in need of care and that they regularly paid visits to older Swedes. A conclusion to be drawn from the survey responses as well as the qualitative interviews was that the parishes and their support were often crucial for older, frail tourists and migrants in need of help, quite possibly in dramatic crisis situations and as a "last resort":

Last week I got a phone call from a travel agent who said "we need help". There was this couple, after two days the wife had disappeared. She had Alzheimer's disease. She had left the hotel and was gone for two days (pastor in a parish in Spain; Study 1).

Nevertheless, pastors and deacons whom we met maintained that the endurance among some of those older Swedes who stayed in the area on a seasonal basis was astonishing, even among those in their "fourth age" and who had considerable care needs: 
In Sweden the authorities would probably had advised him or her to "try to get into a nursing home, or something like that". But you know they manage to get along here. Sometimes I am so astonished at how these really frail old Swedish people get along here ... (pastor in a parish in Spain; Study 1).

However, some pastors who participated in the survey and in the qualitative study also underlined the importance of the parish for resourceful older Swedes. In several of the parishes, they seemed to be the most frequent visitors to the religious services, and it was largely from this group that the volunteers were found.

A majority of respondents in the survey ( 70 per cent), as well as many of the pastors and deacons interviewed in the qualitative study, declared that the Swedish language - and even Swedish customs and culture - had a very important place in the church's activities. Many emphasized the church's role as a bearer of language and culture. Some argued that the preservation of Swedish culture and traditions was particularly important for the older visitors, especially for those who had emigrated early and aged in the country in question. A pastor in a parish located in a large European city (Study 3) stated:

We are a link to that which they may have left behind thirty-fifty years ago, and for them it is important to celebrate a Swedish Christmas, sing the national anthem at celebrations and so on.

The Swedish language and "Swedishness" were also described as very important to those retirees who spent their winters in southern European destinations and who had no or hardly any knowledge of the local language. 
The interviewed older participants themselves, underlined the importance of the church in itself, as a physical space, and the social togetherness that parish life offered. The church was also described as a spiritual meeting place, where "your soul gets help". The church was a place where you could feel safe and "at home", according to several of them. According to some of those interviewed, the fact that the church abroad was a Swedish church was in this sense particularly important:

I have always preferred the Swedish church to other churches. I don't know why but Ifeel more at home here (retired Swedish woman attending a parish in Spain (Study 1).

At the same time, several of the interviewed older Swedes conveyed the opinion that a Swedish parish abroad is different from those in Sweden - more informal and accessible. Pastors and deacons interviewed as part of the qualitative study, confirmed this opinion by underlining that the ritual was simpler and more unconventional than "at home", and was based around the most well-known Swedish hymns.

Unlike the pastors and deacons, none of the older participants, most of whom were regular churchgoers and volunteers, described the church as a place for celebration of Swedish traditions and the Swedish language. A plausible interpretation for this is that they took this aspect of the parish for granted, and therefore thought it was unnecessary to point it out during the interview. Additionally, for quite a few visitors to the Churches of Sweden Abroad, the parishes' ethnic and religious activities and functions appeared to be connected with different phases of their involvement in the parish. A pattern in the qualitative study (Study 1) was the repeated accounts given by pastors and deacons about Swedes who had not been active 
Christians while living in Sweden. However, after a period of participation in the parish's less religious activities, such as having a cup of "Swedish coffee" and a "typically Swedish" cinnamon roll in the parish café, they had begun to participate regularly in the church services, and eventually ended up going to Holy Communion.

\section{How do older Swedes contribute to the activities of the parishes?}

According to the survey (Study3) and the qualitative study (Study1), the older Swedes are not only frequent visitors to the Swedish churches abroad and to the activities in the parishes, including the church services; many of them also carry out extensive unpaid volunteer work. A common saying among the pastors interviewed in the qualitative study was that "without the volunteers we could not run this place". Almost all of them bore witness to how indispensable the unpaid volunteer work was to the running of the parish, the financial resources of which were usually very limited. According to the results from the qualitative interviews with the pastors and deacons, and confirmed in the survey, a variety of tasks were commonly carried out by the older volunteers: sitting on the church board, acting as a churchwarden, making clothes and decorations to be sold at the church bazaar, or singing in the church choir - these were some of the things mentioned. Other tasks had to do with giving support to church visitors, cooking at special church meals, being responsible for the church computers, or participating in renovation of the church. Another volunteer task mentioned in both studies by several of the participating pastors and deacons was that of running the parish café on certain days every week. The retired Swedish volunteers whom we interviewed in Study 1 explained how, in various ways, they contributed to activities in the parish and to its revenues. One example of this was given by a retired migrant couple, Tor and Helga, aged 83 and 88, about their volunteer work in a parish in Southern Europe. It had all started with 
Helga singing in the choir, and now after a number of years as volunteers, the couple had, as Tor said, "taken over running the religious service, all but the sermon":

Tor: /.../ and this room which is normally the place for bridge-playing (of the hotel) needs to be turned into a church room every Sunday. From November to April. And we need to spread the cloth and hang the special picture on the wall....turn it into a church room, and actually it becomes very nice.

Interviewer: And you do this? Are you a group of volunteers?

Helga: No, there is just the two of us. I read the texts, and Tor and I make the collection if there are many that come. ...And this cloth I have sewn ...not the altar cloth but this cloth hanging on the ... what do you call it?

Tor: ...that hangs on the pulpit.

Helga: Yes, I made it ...

Several of the interviewed older volunteers described similar careers; that is, how they had gradually advanced from simple tasks to being responsible parts of the parish activities. A 75year old woman in Spain, for instance told us that she had "started by washing the dishes and had gradually advanced to become a matron's assistant".

Patterns in the qualitative interviews with older church visitors also illustrated how, in a number of ways, retired Swedes involved in the parishes contributed to the work there through their experience and professional, sometimes very specialized, competence. Furthermore, it was clear that the older volunteers were often the ones who represented continuity and local know-how in the parish. While pastors and deacons generally only stayed for a few years, some of the volunteers had been living permanently or on a seasonal basis in 
the community for many years. A 75-year-old woman who had been a volunteer in a parish in the Canary Islands for the past 10 years estimated her volunteer work to be 6-7 hours per week during the 5-8 months that she spent in the area every year. Another active pensioner told us "he had been a churchwarden for the past 17 years".

The sections above have revealed that the older Swedes with whom the parishes of the Church of Sweden Abroad come into contact are a heterogeneous group for which the parishes play an important role in various ways. The parishes of the Church of Sweden Abroad seemed to be particularly important for older Swedes as a meeting place, but also in terms of support, security and assurance - as a physical space and place where they could "feel at home" and a place they knew they could turn to "if something happens". We have also highlighted the important role played by older people themselves in the parishes. A conclusion that may be drawn from the survey and the qualitative study is that the older migrants are vital for the Church of Sweden Abroad, both as visitors and recipients of support who help to legitimize the Church's existence, and by contributing to the parishes' activities and survival with their unpaid work. How then were the older Swedes presented on these websites?

\section{Older Swedes on the websites and in information material}

Curiously enough, in our analysis of the websites of all parishes as well as of different forms of information material about the Church of Sweden Abroad (brochures, etc.), in Study 2, we found that older migrants were hardly presented at all there; in fact, they were literally invisible in these web pages, which were dominated by pictures of young Swedish people and of families with young children. An interesting pattern in our analysis of the websites of all 45 parishes, as well as of the Church of Sweden Abroad on the Church of Sweden's official website and in other types of written material produced by the Church, was the following: 
older visitors to the parishes were neither mentioned nor addressed and the parishes were not presented as meeting places for the older Swedes who come to the area for various lengths of stay. On the other hand, "study", "work", and "youth" were concepts that frequently appeared in these texts, accompanied by photos of obviously young people. The following quote is an illustrative example of how the Church of Sweden abroad was presented on the website of the Church of Sweden Abroad (Svenska kyrkan, 2011c):

Are you going to travel? Or perhaps move abroad for study or for work? You are warmly welcome to visit one of the many parishes of the Church of Sweden Abroad! They can be found in 45 places around the world. There you can meet new people, experience togetherness, and get support at difficult times. Hundreds of thousands of young people, tourists and seamen visit the parishes every year.

Photos of young people and the absence of concepts such as "older", "pensioner" or "senior", also characterised most of the homepages of the local parishes abroad. One of the parishes introduced itself and its activities in the following way: "Here you will find, besides religious worship, meeting places for parents and children, students, young adults and others". A widely distributed brochure published by the Church of Sweden (Svenska kyrkan, 2011d) turned out to be filled with photos of younger adults. Furthermore, an impression from the homepages was that many parishes were primarily focused on programs and activities for children, adolescents and younger adults. Four homepages gave information about activities for older people, but these were actually exceptions. Thus, in the image of itself that the Church of Sweden Abroad advertises on the web and in brochures, there was a very distinct age theme, which implies that certain age categories and phases of life (childhood, youth, young adulthood) dominate, while other ones (the post-retirement time, old age and older people) are accorded a remote or insignificant position. 


\section{Discussion}

The sections above have revealed that the older Swedes with whom the parishes of the Church of Sweden Abroad come into contact are a heterogeneous group for which the parishes play an important role in various ways. The older migrants, in turn, contribute by legitimizing the Church's existence, as visitors and by contributing to the parishes' activities and survival through their unpaid work. The parishes of the Church of Sweden Abroad seemed to be particularly important for older Swedes as a meeting place, but also in terms of support, security and assurance - as a place where they could "feel at home" and that they knew they could turn to "if something happens". Thus, this article has shown that religious immigrant communities may play an important role not only for migrants in vulnerable situations, but also for relatively well-to-do and voluntary older migrants from secularized northern European countries. The results presented also validate the importance of physical spaces for belonging and for having a "feeling of home" (Gustafson 2009).

To a great extent, the migrants who have been the focus of this article are part of an increasing, global ‘voluntary late-life migration', (Becker, Beyne \& Cuizon Canalita, 2000, p.274) consisting of older people who move to other countries, on a seasonal basis or permanently, to pursue comfortable lives, seek new opportunities, or to join adult children. A common image of these older, retired "snowbirds" or "overwinterers" (Breuer, 2005, p.329) moving from Northern Europe to warmer countries is that they are typical third agers (Laslett, 1996): healthy, wealthy and relatively young old age pensioners. Research on retirement migration from different countries in Northern Europe to Spain (e.g. O’Reilly, 2000; Gustafson, 2001; 2008) largely confirms this image, from a wider comparative migration perspective, of a highly privileged group of migrants. The European retirement migration has even been said to lack virtually all the characteristics that have been observed in more recent 
research on transnational migration (Breuer, 2005). However, and as has been shown, ethnic congregations may also fulfil a variety of needs for these migrants, who according to our results, also include migrants who are very old and neither wealthy nor healthy. Many of them could be categorised as fourth rather than third agers as they are very old (aged 85-90) and in several cases frail and in need of care (Baltes \& Smith, 2003).

Plausible explanations for the high proportion of older migrants involved with the parishes are that the congregations not only provide opportunities for worship and religious practice, and perhaps for spiritual support, but also opportunities for fellowship with other older (Swedishspeaking) Swedes. The parishes also offer ways to occupy free time, not least by substituting for previous paid work by volunteering. Since biological aging increases the risk of various medical conditions, older Swedes as a group are also more dependent than other, younger, Swedes on the care services that the parishes offer. The churches thus meet a variety of needs of migrating older Swedes. Furthermore, the parishes' less religious activities and roles seem to function as a kind of door opener into religious practice to many Swedes who have not been active Christians in Sweden. That this stepwise process into religious participation is not unusual among Swedes who visit the Church of Sweden's parishes abroad was confirmed by the Church of Sweden's organizational report (Svenska kyrkans utvärderingar 2001:1). A similar process has been observed among churchgoers in the Norwegian Seamen's Churches abroad (Aagedal, 2007) as well as among older Chinese immigrants in the U.S. (Gehui \& Heying, 2009).

To sum up, the analysis presented in this article challenges the dominant understanding of migrants' engagement in religious practices as related to difficulties connected with migration and to experiences of racism, exclusion and discrimination in the new country (i.e. Hagan and 
Ebaugh 2003). They also point to the importance of including older migrants as well as various types of more voluntary migrants in research on migration and immigrant religious communities.

Why the youthful facade?

However, while the results of the survey and the qualitative study clearly indicate that people aged 65+ in practice "carry" many of the parish activities - and are often "carried" themselves by the parishes in terms of receiving various forms of support, this age group was virtually invisible in the photographs and texts on the parish websites. The same invisibility characterized the space of the Swedish Church Abroad in the main, over-arching webpage of the Church of Sweden and other official information materials about the church that were studied. One explanation for why older people were virtually invisible on the "public face" of the Church of Sweden Abroad and its parishes may be that older people are the largest group and already dominate the parishes' activities. Consequently, there is no need to invite more older visitors. Or, as one of the interviewed pastors put it: "The thing is that we do not say that this is intended for older people, but the older people will be there [anyway]." There were also those among the pastors and deacons who underlined that it was important for the staff in the parish to make sure that the high proportion of older visitors did not turn the parish into a sort of community for older people, where younger adults, children and teenagers did not feel that they were wanted or welcome. A pastor in a parish in Spain:

What I would like to develop in terms of church services and activities are things for families and those who are my age, forty. So that it does not just turn into a congregation for older people /... / We have Sunday school almost every Sunday even if there are not many children who attend. But it's a way to get the parish to think about the children and also a way to make families with children aware that they are welcome. And also to think of the au-pairs who are 
here, and those who are twenty plus, eighteen plus, too./ ... / ... / If we want a bunch of young people here too, if we wish that some families with children would come, then we must plan it beforehand.

Among the interviewed older people there were, however, those who expressed a certain desire for activities adjusted to the needs that people in later life may have. An older volunteer in a southern European parish where there were many older visitors gave the following answer to the question Is there any type of activity that you think the parish ought to develop?

The respondent: Yes. Maybe a group for older people/.../Existential questions and so on /.../. And that it is not so scary to die/.../ And ... many people go around fearing illness and such things. Maybe invite an expert to talk. That is not difficult to find here/.../a lot of older people go about and are afraid of things that they do not need to be afraid of...

An inadvertent case of ageism?

The social gerontological concept of ageism provides another possible explanation for the discrepancy between the focus on young people on websites and in information material and the high proportion of older people in the parishes. The concept of ageism was coined by the American gerontologist Robert Butler in the 1960s "to identify the stereotypes to which people are subjected when they grow old" (Butler, 2005). Similar to the terms 'racism' and 'sexism', ageism may today refer to the discrimination, neglect, or simply assignment of negative stereotypes to older persons, and covers both conscious and explicit attitudes and discriminatory acts as well as more implicit, unreflective attitudes; that is to say a neglect of, or negative attitudes to older people (Andersson, 2002). 
Thus, another explanation for the invisibility of older people in the official image that the Church of Sweden Abroad and its parishes presents may be a certain ageism. This could also imply a more positive opinion of children, adolescents and younger adults than of people in later life, which has to do with grading what is valuable (Andersson, 2002). By this, we do not mean that the parishes of the Church of Sweden abroad have a planned ageist strategy. It might just be that there is a general assumption in the Church of Sweden Abroad that photos and texts that mirror the real situation, i.e. that many activities are dominated by older people, would not attract as many visitors as those with more youthful allusions. In other words, they have uncritically adapted their information and the "launching" of the church abroad and its parishes on the websites and other material to ageist attitudes and ideas about people of different ages in the culture that surrounds them. The youthful façade presented by the Church is in line with common marketing trends, characterized by a youth-obsessed, and ageist culture, that is so prominent in many contexts today. A study of commercials in weekly magazines in the USA and Sweden (Wiles, Wiles \& Tjernlund, 1996) highlighted, for instance, that the majority of people appearing in these commercials were between 16 and 30 years of age, while people $65+$ were hardly seen at all.

Our argument about ageism in the Church of Sweden Abroad is supported not only by the analysis of websites and information material presented above, but also by the survey and the qualitative interviews with pastors and deacons. First, when asked if the parish organized age-related activities, in the survey as well as in the qualitative interviews, most responding pastors and deacons brought up children and parents' groups, au-pair groups, preschool activities, Sunday school and religious services for families with children, etc., while older people and their activities were not mentioned. Similarly, in the open questions about the parish and its activities in general, in Study 3 as well as in Study 1, the respondents seldom 
spontaneously mentioned older people and their interests. This is in line with an age pattern found in a study of diaconal work in Church of Sweden parishes in two Swedish communities (Jeppsson Grassman, 2001). The fact that the Church of Sweden Abroad has presented the Church and its parishes as "youthful”, does indeed challenge ideas and empirically-based arguments put forward by some scholars about churches as probably less ageist than "any other institution in our society" (Seymor, 2005, p.71) and Christianity as not sharing "the contemporary tendency to value people according to productivity and youthful appearance" (Gehui \& Heying, 2009, p.297).

Is the Church of Sweden Abroad in this sense then an exception in the world of churches? How do churches and religious congregations in other parts of the world deal with the potential "problem" of attracting younger visitors to a religious community where older people are the majority? These are questions for further studies.

\section{References}

Aagedal, O. (2007). The Norwegian Seamen’s Church as a National Symbol. An essay on migration, religion and national identity. In I. Furseth \& P. Leer-Salvesen, P (eds), Religion in Late Modernity. Essays in Honour of Pål Repstad (pp. 55-68). Trondheim: Tapir Academic Press.

Andersson, L. (2002). Ålderism (Ageism). In L. Andersson (ed.), Socialgerontologi (pp., 104127). Lund: Studentlitteratur. 
Baltes, P.B. \& Smith, J. (2003). New frontiers in the future of aging: From successful aging of the young old to the dilemmas of the fourth age. Gerontology, 49(2), 125-135.

Beattie, L. \& Ley, D. (2003). The German Immigrant Church in Vancouver: Service provision and Identity Formation. Die Erde, 134(1), 3-22.

Becker, G., Beyene, Y. \& Cuizon Canalita, L. (2000). Immigrating for Status in Late Life: Effects of Globalization on Filipino American Veterans. Journal of Aging Studies, 14(3), 273-292.

Bergmark, I. (1974). Kyrka och sjöfolk: En studie i Svenska kyrkans sjömansvård 1911-1933 [Church and Seamen: A Study of the Seamen Care by the Church of Sweden, 1911-1933]. Stockholm: Verbum.

Butler, R., N. (2005). Foreword. In E. B Palmore, L. Branch \& D.K. Harris (eds), Encyclopedia of Ageism (pp. xv-xvi). New York, Binghampton: The Haworth Press.

Breuer, T. (2005). Retirement migration or rather Second-Home Tourism? German Senior Citizens on the Canary Islands. Die Erde, 136(3), 313-333.

Bäckström, A. (1995). Londonsvenskarna och Kyrkan. En studie av kulturupplevelser [The Swedes in London and the Church. A Study of Cultural Experiences]. Uppsala: Svenska kyrkans församlingsnämnd. 
Cadge, W. \& Howard Ecklund, E. (2006). Religious Service Attendance Among Immigrants:

Evidence from the New Immigrant Survey-Pilot. American Behavioral Scientist, 49(11), 1574-1595.

Campbell, H. (2011). Internet and religion. In M. Consalvo \& C. Ess (eds), Handbook of Internet Studies (pp. 236-250). Oxford: Wiley-Blackwell.

Ebaugh, H. R. \& Chafetz, J., S. (2000). Religion and the New Immigrants: continuities and adaptations in immigrant congregations. Walnut Creek, CA: Altamira Press.

Furseth, I. (2008). Social capital and immigrant religion. Nordic Journal of Religion and Society, 21(2), 147-164.

Gehui Z. \& Heying, J. Z. (2009). Beyond the Bible and the cross: a social and cultural analysis of Chinese elders' participation in Christian congregations in the United States, Sociological Spectrum: Mid-South Sociological Association, 29(2), 295-317.

Gustafson, P. (2001). Retirement migration and transnational Lifestyles. Ageing and Society, 21(4), 371-394.

Gustafson, P. (2008). Transnationalism in retirement migration: the case of North European retirees in Spain. Ethnic and Racial Studies, 31(3), 451-475.

Hagan, J. \& Ebaugh, H. R. (2003). Calling Upon the Sacred: Migrants' Use of Religion in the Migration Process. International Migration Review, 37(4), 1145-1162. 
Inglehart, R., Basafiez, M., Diez-Medrano, J., Halman, L. \& Luijkx, R. (2004). Human Beliefs and Values. Mexico City: Siglo XXI Editores.

Jeppsson Grassman, E. (2001). Socialt arbete i församlingens hägn [Social Work in the Parish]. Stockholm: Verbum.

Kverndal, R. (1986). Seamen's Missions - Their Origin and Early Growth. A Contribution to the History of the Church Maritime. Pasadena: William Carey Library.

Laslett, P. (1996). A Fresh Map of Life. The Emergence of the Third Age. Hampshire \& London: Macmillan Press Ltd.

McFadden, S. H. (1995). Religion and Well-Being in Aging Persons in an Aging Society. Journal of Social Issues, 51(2), 161-175.

Min, P.G. (1992). The structure and social functions of Korean immigrant churches in the United States. International Migrant Review, 6, 1370-1394.

Murray, R. (1980). Den svenska utlandskyrkan. Upprinnelse, problematik, vidareutveckling [The Church of Sweden Abroad. Origins, Problems, Development]. In R. Norrman (ed.), Stiftshistoriska perspektiv (pp. 89-97).Uppsala: Ärkestiftets herdaminneskommitté.

O’Reilly, K. (2000). The British on the Costa del Sol: Transnational Identities and Local Communities. London: Routledge. 
Peschke, D. (2009). The role of religion for the integration of migrants and institutional responses in Europe: Some reflections. The Ecumenical Review, 61(4), 367-380.

Renström, C. (1926). I hamnar och storstäder. Svenska kyrkans sjömansvård och diasporaverksamhet under femtio år [In Ports and Cities. The Seamen Care and Diaspora Activities by the Church of Sweden over fifty years]. Stockholm: Svenska kyrkans diakonistyrelses bokförlag.

Sjödin, D. (2011). Tryggare kan ingen vara: migration, religion och integration $i$ en segregerad omgivning [Migration, Religion and Integration in a Segregated Environment] . Lund: Lunds universitet. Lund Dissertations in Sociology 98.

Seymor, R. (2005). Churches. In E. B Palmore, L. Branch \& D.K. Harris (eds), Encyclopedia of Ageism (p.71). New York, Binghampton: The Haworth Press.

Spellman, K. (2006). Religion and Nation. Iranian Local and Transnational Networks in Britain. Oxford: Berghahn Books.

Svenska kyrkan (2011a). Mötesplatser världen över [Meeting Places All Over the World]. Uppsala: Svenska kyrkan. Available from: http://www.svenskakyrkan.se/default.aspx?id=647744 [Accessed 31 January 2011].

Svenska kyrkan (2011b). Kyrkans grundläggande uppgifter [The Tasks of the Church]. Uppsala: Svenska kyrkan. Available from: http://www.svenskakyrkan.se/default.aspx?id=642644 [Accessed 31 January 2011]. 
Svenska kyrkan (2011c). Välkommen till utlandskyrkan [Welcome to the Church of Sweden Abroad]. Uppsala: Svenska kyrkan. Available from:

http://www.svenskakyrkan.se/default.aspx?id=693978 [Accessed 22 October 2011].

Svenska kyrkan (2011d). Som hemma fast utomlands - om Svenska kyrkan i utlandet [ Like at Home but in Foreign Countries. The Church of Sweden Abroad]. Available from: http://www.svenskakyrkan.se/default.aspx?id=578247 [Accessed 12 December 2011].

Svenska kyrkans utredningar 2001: 1. Svenska kyrkan i utlandet - organisation och uppgifter. [The Church of Sweden Abroad - Organization and Functions]. Betänkande från 1998 års SKUT-utredning. Uppsala: Svenska kyrkan.

Svenska kyrkans utredningar 2009:1. Utlandskyrkan. Struktur och delaktighet [The Church of Sweden Abroad. Structure and Participation]. Slutbetänkande från den av kyrkostyrelsen tillsatta utredningen om förändrad organisation av Svenska kyrkan i utlandet. Uppsala: Svenska kyrkan.

Weibull, L. \& Strid, J. (2011).Fyra perspektiv på religion i Sverige [Four Perspectives on Religion in Sweden]. In S. Holmberg, L. Weibull \& H. Oscarssons (eds), Lycksalighetens $\ddot{o}$ (pp. 331-348). Gothenburg: University of Gothenburg.

Wiles, C. R., Wiles, J. A. \& Tjernlund, A. (1996). The ideology of advertising: The United States and Sweden. Journal of Advertising Research, 36(3), 57-66. 
Zuckerman, P. (2009). Why are Danes and Swedes so irreligious? Nordic Journal of Religion and Society, 22(1), 55-69. 